\title{
Importance of MRI in Showing the Early Period Erosive Alterations During Wrist Involvement in Rheumatoid Arthritis
}

\author{
Romatoid Artritte El Bileği Tutulumu Sırasında MRG'nin Erken Dönem Erozif \\ Değişikliklerin Ortaya Konmasındaki Önemi
}

Gökhan GÖKALP, Zeynep YAZICI

Departments of Radiology, Medical Faculty of Uludă̆ University, Bursa, Turkey

Objectives: In this study, we aimed to evaluate the efficacy of magnetic resonance imaging (MRI) in demonstrating erosive alterations during the early period of rheumatoid arthritis (RA).

Patients and methods: Twenty-one wrists of 14 patients (11 females, 3 males; mean age 54 years; range 37 to 64 years) diagnosed with RA by clinical data and laboratory results were examined with $\mathrm{MRI}$. The disease activity was determined by C-reactive protein and erythrocyte sedimentation rates. Wrist radiographies of all the patients were either normal or had suspicious signs. The presence of bone erosion was evaluated in 15 different regions (8 carpal bones, 5 metacarpal heads, 1 distal radius, and 1 distal ulna). Coronal and axial T1-weighted spin echo (SE) images with and without fat suppression, coronal T2-weighted turbo SE images with fat suppression, and coronal T1-weighted SE images with fat suppression following administration of intravenous gadopenteate dimeglumine were obtained.

Results: In all cases, the wrist radiographs were either normal or exhibited suspicious findings. Bone erosion was found in $73(81.1 \%)$ different sites in carpal bones, four different sites in distal radius $(4.4 \%)$, four $(4.4 \%)$ different sites in distal ulna, and nine (10\%) different sites in proximal metacarpal heads. While capitatum $(27.3 \%)$ and triquetrum $(24.6 \%)$ were the most commonly affected sites, pisiforme (1.6) was found be the least affected site. Among the 21 wrist MRIs showing erosion, nine (42.8\%) had synovitis, three (14.2\%) had tenosynovitis, two $(9.5 \%)$ had bursitis, and seven (33.3\%) had bone marrow edema.

Conclusion: Magnetic resonance imaging may be an effective diagnostic method for the determination of early period joint involvement in RA cases.

Key words: Erosion; magnetic resonance imaging; rheumatoid arthritis.
Amaç: $\mathrm{Bu}$ çalışmada, romatoid artritin (RA) erken dönem eroziv değişikliklerinin ortaya konmasında, manyetik resonans görüntülemenin (MRG) etkinliği değerlendirildi.

Hastalar ve yöntemler: Klinik veriler ve laboratuvar sonuçlarıyla RA tanısı konulan 14 hastada (11 kadın, 3 erkek; ort yaş 54 yıl; dağılım 37-64 yıl) 21 el bileği MRG ile incelendi. Hastalık aktivitesi C-reaktif protein ve eritrosit sedimantasyon oranı ile belirlendi. Hastaların hepsinde el bileği grafisi normaldi ya da şüpheli bulgular vardı. Kemik erozyonlarının varlığı 15 farklı bölgede (8 karpal kemik, 5 metakarp başı, 1 distal radius ve 1 distal ulna) değerlendirildi. Yağ baskılamalı ve yağ baskılamasız koronal ve aksiyal T1-ağırlıklı spin eko (SE) görüntüleri, yağ baskılamalı T2-ağırlıklı koronal turbo $S E$ görüntüleri ve intravenöz gadopentetat dimeglumin verilmesinden sonra yağ baskılamalı T1-ağırlıklı koronal SE görüntüleri elde edildi.

Bulgular: Olguların hepsinde el bileği grafisi ya normaldi ya da şüpheli bulgular vardı. Karpal kemiklerde 73 (\%81.1) farklı bölgede, distal radiusta dört (\%4.4) farklı bölgede, distal ulnada dört (\%4.4) farklı bölgede, proximal metakarp başlarında dokuz (\%10) farklı bölgede kemik erozyonu tespit edildi. Kapitatum (\%27.3) ve triquetrum (\%24.6) en çok ekilenen bölge iken, pisiforme en az etkilenen bölge (\%1.6) olarak tespit edildi. Erozyon saptanan 21 elbileği MRG'sinin dokuzunda (\%42.8) sinovit, üçünde tenosinovit (\%14.2), ikisinde bursit (\%9.5) ve yedisinde kemik iliği ödemi (\%33.3) vardı.

Sonuç: Manyetik resonans görüntüleme RA'lı olgularda erken dönem eklem tutulumunu saptamada etkin bir tanı yöntemi olabilir.

Anahtar sözcükler: Erozyon; manyetik rezonans görüntüleme; romatoid artrit.

Received: July 12, 2009 Accepted: February 16, 2010

Correspondence: Gökhan Gökalp, M.D. Uludağ Üniversitesi Tıp Fakültesi Radyoloji Anabilim Dalı, 16059 Nilüfer, Bursa, Turkey.

Tel: +90 224 - 2953322 e-mail: drgokhangokalp@yahoo.com

C2011 Turkish League Against Rheumatism. All rights reserved. 
Rheumatoid arthritis (RA) is a systemic inflammatory disease characterized by proliferative hypervascularized synovitis which primarily affects synovial joints. Synovium of bursa; tendon sheaths; attachment sites of cartilage, ligament, and tendons to the bone; soft tissue; and bones can be mentioned among the other areas under influence of RA. Changes happen to be symmetrical and may present as fusiform soft tissue swelling, regional osteoporosis, marginal-central erosions, cartilage damage, joint destruction, narrowing of joint space and fibrous ankylosis. Wrist, metacarpophalangeal and metatarsophalangeal joints are the first sites to be affected..$^{[1-10]}$

According to the epidemiological data, RA affects $1 \%$ of the population. While it shows a slow progression in some patients, in some it has a course characterized by rapid destruction of the bone and joint space. Initial symptoms are observed in people between the ages of 40-60 years old. ${ }^{[4]}$

Diagnosis is established by clinical, laboratory, and radiological findings. As a result of advanced treatment methods, early diagnosis bears importance in preventing arthritis from progression to advanced stages. Radiography falls short in showing bone damage in the early period..$^{[7,10,11]}$ Magnetic resonance imaging (MRI) and ultrasonography can be useful tools in evaluating patients with early rheumatoid arthritis. Magnetic resonance imaging allows direct visualization and assessment of synovitis, the primary lesion in RA, and of bone edema, a finding unique to MRI and a probable forerunner of bone erosions. ${ }^{[12]}$ The first study comparing MRI and X-ray scanning of the wrist joint of RA patients was published in $1988{ }^{[13]}$ Since then, a large number of publications using MRI in RA have demonstrated its usefulness in the detection of early period inflammatory and structural changes in RA cases. ${ }^{[1-12,14,15]}$ Moreover, MRI is the ideal instrument for the evaluation of treatment response. ${ }^{[16]}$ Since 1998, an international Outcome Measures in Rheumatology Clinical Trials (OMERACT) MRI in an RA working group has aimed to develop MRI scoring systems to assess RA inflammation (activity) and damage which would satisfy the elements of the OMERACT filter (truth, discrimination, and feasibility). ${ }^{[12,17]}$ The OMERACT MRI group has published definitions of important RA pathologies and basic recommendations of MRI sequences selection. The group has also delivered a reference image atlas for scoring synovitis, bone marrow edema, and erosions in RA wrist and metacarpophalangeal joints. ${ }^{[18,19]}$ It indicates an improved sensitivity to change for erosive joint damage by using this MRI score as compared with radiography, particularly in early disease..$^{[12,20-25]}$

Our aim is to evaluate the efficacy of MRI in showing erosive changes in the early period of RA cases.

\section{PATIENTS AND METHODS}

\section{Patient selection}

Among 14 patients, (11 females, 3 males; mean age 54 years; range 37 to 64 years) diagnosed as RA based on the clinical and laboratory data, 21 wrists were retrospectively evaluated. Rheumatoid arthritis diagnosis was established according to the

\begin{tabular}{|c|c|c|c|}
\hline & \multicolumn{3}{|c|}{ Rheumatoid arthritis $(\mathrm{n}=21)$} \\
\hline & $\mathrm{n}$ & Median & Range \\
\hline Age (years) & & 54 & $37-64$ \\
\hline \multicolumn{4}{|l|}{ Sex } \\
\hline Female & 11 & & \\
\hline Male & 3 & & \\
\hline Disease duration (years) & & 5 & $1-6$ \\
\hline \multicolumn{4}{|l|}{1987 ACR criteria for rheumatoid arthritis } \\
\hline Morning stiffness & $21 / 2$ wrist & & \\
\hline Arthritis of three or more joint areas & $21 / 21$ wrist & & \\
\hline Arthritis of hand joints & $21 / 21$ wrist & & \\
\hline Symmetric arthritis & $17 / 21$ wrist & & \\
\hline Rheumatoid nodules & $2 / 21$ wrist & & \\
\hline Serum rheumatoid factor & $16 / 21$ wrist & & \\
\hline Radiographic changes & $0 / 21$ wrist & & \\
\hline
\end{tabular}


Table 2. Activity of the disease

\begin{tabular}{lcc}
\hline & \multicolumn{2}{c}{ Rheumatoid arthritis $(\mathrm{n}=21)$} \\
\cline { 2 - 3 } & Mean & Range \\
\hline C-reactive protein $(\mathrm{mg} / \mathrm{dl})$ & 1.08 & $0.2-2.25$ \\
ESR $\left(\mathrm{mm} \mathrm{1}^{\text {st }} \mathrm{h}\right)$ & 24.95 & $4-38$ \\
\hline ESR: Erythrocyte sedimentation rate. & & \\
\hline
\end{tabular}

diagnostic criteria outlined by American College of Rheumatology (ACR) in 1987. ${ }^{[1]}$ Patients having symptoms for six months or less (mean value 5 months) were included in the study. Activity of the disease was determined by $\mathrm{C}$-reactive protein and erythrocyte sedimentation rate. The ethical committee of our hospital approved our study. Since our aim was to determine presence versus absence of pathology without attempting to quantify its severity, scoring for synovitis and erosions according to the OMERACT Rheumatoid Arthritis Magnetic Resonance Imaging Studies system was not performed.

\section{Imaging}

Conventional radiography of the wrist was acquired in the posteroanterior (PA) and semisupine projections. All the radiographs and MRIs were evaluated randomly and separately by a musculoskeletal system radiologist (GG with 6-year experience) at different times. Magnetic resonance imaging examination of the wrist was performed on both sides in six patients and on the dominant side in eight patients by a 1.5 Tesla MR (Magnetom Vision, Siemens, Medical Solutions, Erlangen, Germany) with surface coil. The examination site was $8 \mathrm{~cm}$ and set to encompass radioulnar, radiocarpal, midcarpal, and proximal metacarpal heads. Fat-suppressed and non-fat-supressed coronal and axial T1-weighted spin echo (SE) (TR $656 \mathrm{~ms}$, TE $12 \mathrm{~ms}$, slice thickness $3 \mathrm{~mm}$, matrix $154 \times 256$, acquisitions 2), coronal fat-suppressed T2-weighted turbo spin echo (TSE) (TR 4000, TE 54, flip angle $180^{\circ}$, slice thickness 3 $\mathrm{mm}$, matrix 140x256, acquisition 1) or coronal short inversion time inversion recovery (STIR) sequence (TR 5600, TE 30, TI 150, flip angle $180^{\circ}$, slice thickness $3 \mathrm{~mm}$, matrix $140 \times 256$, acquisitions 2) and following delivery of $0.1 \mathrm{mmol} / \mathrm{kg}$ intravenous gadopentetate dimeglumine contrast agent, coronal fat-suppressed T1-weighted SE (TR $656 \mathrm{~ms}$, TE $12 \mathrm{~ms}$, slice thickness $3 \mathrm{~mm}$, matrix $154 \times 256$, acquisitions 2) images, were acquired.

\section{Bone erosions}

Presence of bone erosions were evaluated in 15 different anatomical regions (8 carpal bones, distal radius, distal ulna, 5 metacarpal heads). All the erosions were defined as single or multiple focal areas with sharp and regular margins causing defects in the cortical and subcortical bone marrows. Lesions with low signal intensity on T1-weighted images, high signal intensity on T2-weighted images and enhanced after contrast material administration were identified as bone erosions.

\begin{tabular}{|c|c|c|c|c|}
\hline \multirow[t]{2}{*}{ Magnetic resonance imaging feature } & \multicolumn{2}{|c|}{ Wrist } & \multicolumn{2}{|c|}{ Most common sites } \\
\hline & $\mathrm{n}$ & $\%$ & $\mathrm{n}$ & $\%$ \\
\hline Erosions & 21 & 100 & & \\
\hline Carpal bones & & & 73 & 81.1 \\
\hline Capitate & & & 20 & 27.3 \\
\hline Triquetral & & & 18 & 24.6 \\
\hline Scaphoid & & & 11 & 15 \\
\hline Lunate & & & 8 & 10.9 \\
\hline Trapezoid & & & 6 & 8.2 \\
\hline Hamate & & & 6 & 8.2 \\
\hline Trapezium & & & 3 & 4.1 \\
\hline Pisiform & & & 1 & 1.3 \\
\hline Distal radius & & & 4 & 4.4 \\
\hline Distal ulna & & & 4 & 4.4 \\
\hline Proximal metacarpal & & & 9 & 10 \\
\hline Synovitis & 9 & 42.8 & & \\
\hline Tendonitis & 3 & 14.2 & & \\
\hline Bursitis & 2 & 9.5 & & \\
\hline Bone marrow edema & 7 & 33.3 & & \\
\hline
\end{tabular}



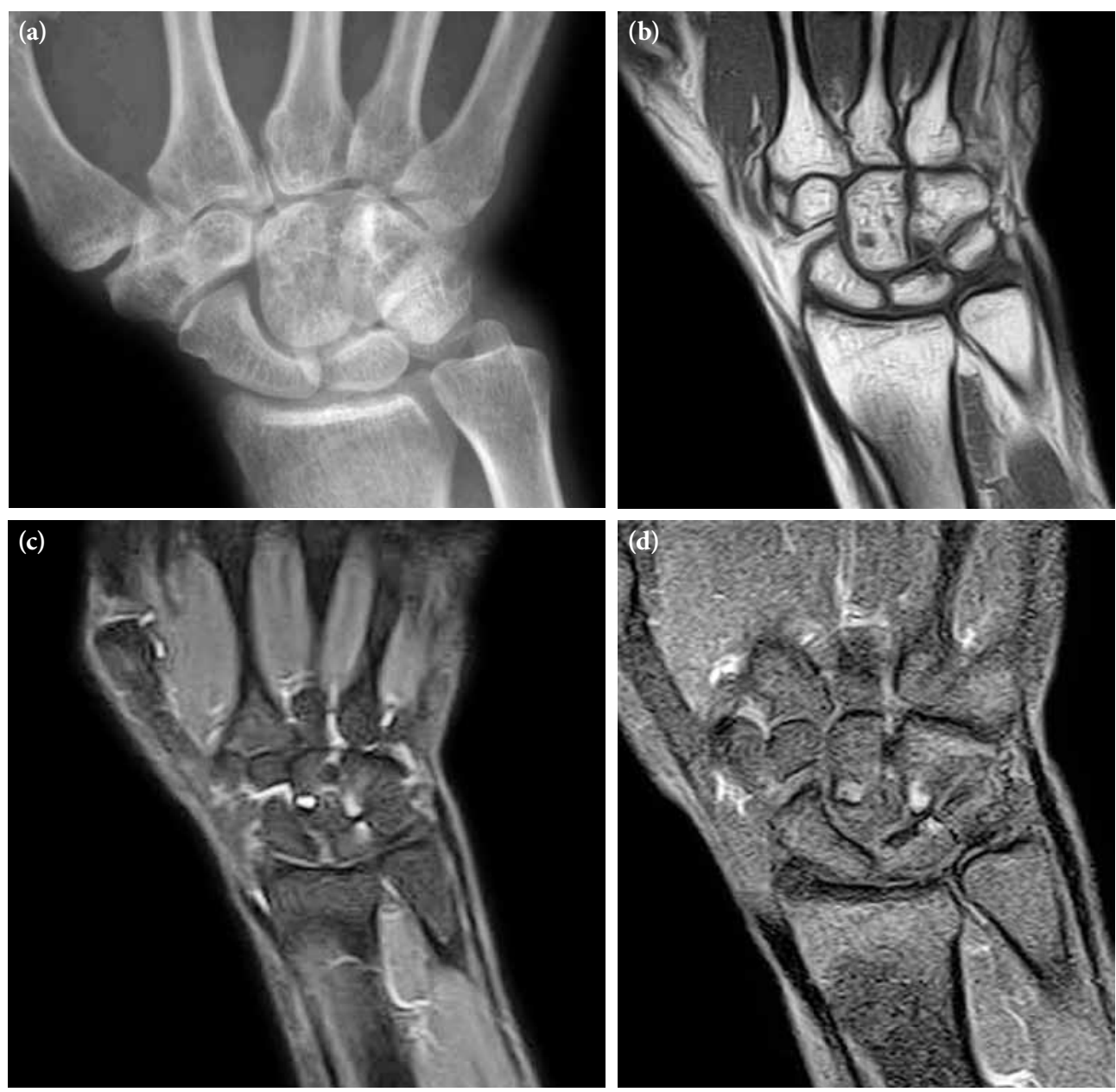

Figure 1. A 48-year-old female patient with rheumatoid arthritis under follow-up for five months. (a) Radiograph of right wrist is normal except for a suspicious erosion in the capitate. (b) Coronal T1-weighted magnetic resonance image of the right wrist shows hypointense subcortical lesion with sharp margins in the lunate and hamate joint surfaces and in the capitate. (c) Coronal short inversion time inversion recovery magnetic resonance image shows a lesion with high signal intensity. (d) Coronal fat-suppressed contrast-enhanced T1-weighted magnetic resonance image shows prominent enhancement of the lesions supporting erosion and activity. Absence of synovial inflammation appears to be a remarkable finding.

\section{Synovitis and tenosynovitis}

Synovitis was defined as staining and thickening of the synovial membrane with the contrast agent in a diffuse and regular way.

\section{Bursitis}

Bursitis was defined as an oval circumferential enhancement in the intermetatarsal and submetatarsal region between metatarsal heads accompanied by a contrast agent and fluid collection on T1-weighted fatsuppressed images.

\section{Bone marrow edema}

Bone marrow edema was defined as lesions within the trabecular bone with irregular margins and high signal intensity on STIR or T2-weighted images.

\begin{abstract}
RESULTS
All the cases had a radiograph which was either normal or with suspicious erosions. Magnetic resonance imaging showed $73(81.1 \%)$ bone erosions over different sites in carpal bones, four (4.4\%) in distal radius, four $(4.4 \%)$ in distal ulna, and nine (10\%) in proximal metacarpal heads. All the erosions were single or multiple and non-adjacent focal while showing low signal intensity on T1-weighted images with contrast enhancement and high intensity signals on T2-weighted images (Figure 1-3). No bone marrow edema signs which are seen in the advanced stages of the disease as diffuse or converging signal changes were observed. Capitate was the site having the
\end{abstract}



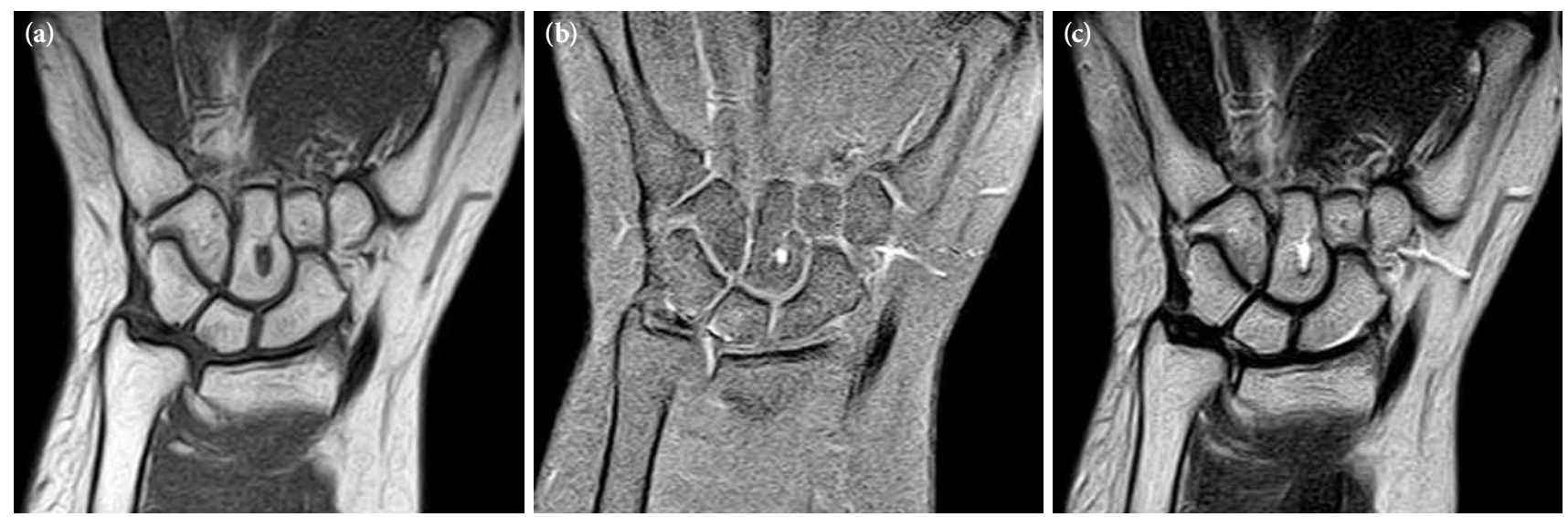

Figure 2. A 55-year-old female patient with rheumatoid arthritis under follow-up for four months. (a) Coronal T1-weighted magnetic resonance image of the left wrist revealing hypointense lesion with sharp margins in the capitate. (b) Lesion with high signal intensity on T2-weighted coronal magnetic resonance image. (c) Coronal fat-suppressed contrast-enhanced T1-weighted magnetic resonance image shows prominent enhancement of the lesion supporting erosion and activity.

highest number of erosions with 20 (27.3\%), followedby triquetral, scaphoid, lunate, trapezoid, hamate, trapezium, and pisiform having 18 (24.6\%), 11 (15\%), eight (10.9\%), six (8.2\%), six (8.2\%), three (4.1\%), and one $(1.3 \%)$ erosion, respectively.

Among the twenty-one cases showing erosion in the MRI, nine (42.8\%) showed synovitis findings whereas 12 had no such sign. Three (14.2\%) of the cases had synovitis and two had (9.5\%) bursitis. Bone marrow edema was found only in seven $(33.3 \%)$ of the cases.

\section{DISCUSSION}

Due to advanced therapeutic methods, early diagnosis is important in RA. The earliest pathological symptom is acute synovitis. However, the relationship between synovitis and bone changes is contentious. A study has shown a weak relationship between synovitis and progression in bone changes. ${ }^{[26]}$ Nonetheless, another study has described their relationship as strong. ${ }^{[23]}$ In the current study, we determined synovitis frequency as 42 percent. Haavardsholm et al. ${ }^{[21]}$ conducted a study and reported development of bone marrow edema due to inflammatory activation which acts as a precursor to erosive changes. McQueen and Ostendorf ${ }^{[27]}$ demonstrated that erosions might start in the bone marrow through an inflammatory release of cytokines stimulating osteoclasts to resorb the bone. Thus, erosions are among the early period changes in RA and detecting them is important. By early diagnosis, irreversible joint damage and eventual
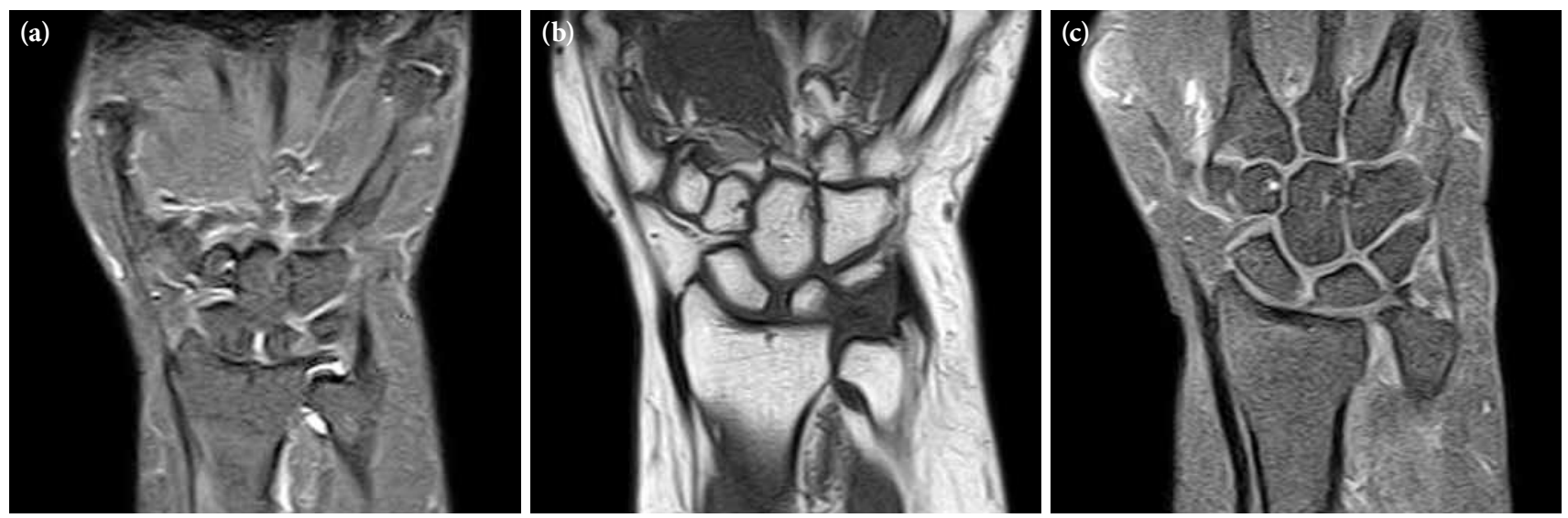

Figure 3. A 53-year-old female patient under follow-up for five months for rheumatoid arthritis. (a) Right wrist magnetic resonance examination shows focal lesion with high signal intensity in the trapezoid on the coronal short inversion time inversion recovery image. (b) Subcortical and hypointense lesion with sharp margins on the T1-weighted coronal image. It is not possible to define it as a typical erosive change. (c) Significant contrast enhancement on the fat-suppressed contrast enhanced magnetic resonance image supports bone erosion. It would be difficult to differentiate the lesion from a bone islet if the image had not shown contrast enhancement. 
complications can be prevented. Erosions show a frequency of more than $47 \%$ in the year following the beginning of the disease. ${ }^{[1]}$

Magnetic resonance imaging can detect erosions in the early period. Fleming et al ${ }^{[28]}$ revealed that MRIs from RA patients demonstrate several positive findings even when conventional radiographs are normal. Other investigations demonstrated that erosions on radiographs were evident on MRI a median of two years earlier and that MRI could be a superior tool for tracking progression of RA in patients. ${ }^{[29,30]}$

McQueen et al. ${ }^{[23]}$ determined an erosion rate of $45 \%$ in the MRI and $15 \%$ in the conventional radiography four months after the beginning of the symptoms. While radiography is a conventional method used for diagnosis, staging, follow-up, and monitoring of treatment efficacy, it is not a sensitive modality for detection of early erosions. They may not be detected owing to the superposition of the bones. It is difficult to determine particularly the intramedullary-penetrated erosions surrounded by the bone. Because MRI is based on sections, it shows not only the erosions on the dorsal and volar plane, but also the ones that are penetrated. ${ }^{[26]}$ Magnetic resonance imaging has been shown to be very sensitive in detecting erosions. ${ }^{[31,32]}$ Besides detecting erosions in the early period, MRI has a multiplanar feature which is efficient in showing complications such as synovitis, pannus, synovial fluid, bursitis, and tenosynovitis. Moreover, MRI practices with intravenous gadolinium administration can discriminate pannus formation from synovial fluid. In cases where a contrast agent is not delivered, this is quite a problem, and thickened synovium cannot be distinguished from intraarticular fluid on T2-weighted images.

On MRIs, erosions appear as trabecular bone loss with sharp margins accompanied by cortical defect. Erosions can be more clearly observed following intravenous gadolinium injection.

In the current study, we found bone erosion in all the cases with a normal or suspicious wrist radiograph. Our study shows the superiority of MRI over conventional radiography in detection of early stage erosive changes. By adding contrast studies, detection of erosive changes becomes easier. Moreover, the extent and complications of the disease can be evaluated better.
In the present study, we determined erosion mostly in the carpal bones of the wrist. The most frequently affected carpal bones were capitate $(27.3 \%)$ and triquetral (24.6\%) whereas the least commonly affected bone was pisiform (1.6\%).

In our study, synovitis was found in nine $(42.8 \%)$ of 22 wrist examinations which indicated no strong relationship between erosive changes and synovitis. Synovial thickening or enhancement may not exist in the presence of erosions stained by the contrast which supports the study of Kirvan. ${ }^{[33]}$ However, further studies including a larger number of cases are required.

The first limitation of our study was the low number of cases. The second limitation was the conventional nature of the radiographs which were unable to demonstrate adequate quality. The third limitation was the inability to image sections thinner than $3 \mathrm{~mm}$ due to the occurrence of an increase in imaging duration and reduction in contrast resolution.

In conclusion, MRI may an effective diagnostic method in the detection of early stage joint involvement and the determination of the disease activity in RA cases. In patients suspected of having arthritis, if the diagnosis is based on radiological findings, then MRI should be preferred over conventional radiography. In particular, contrast enhancement on T1-weighted images in areas suspected of erosive change supports bone erosion. In cases where synovial thickening and contrast enhancement are not present, erosive changes may occur all the same. Further studies are needed on this subject.

\section{Declaration of conflicting interests}

The authors declared no conflicts of interest with respect to the authorship and/or publication of this article.

\section{Funding}

The authors received no financial support for the research and/or authorship of this article.

\section{REFERENCES}

1. Sommer OJ, Kladosek A, Weiler V, Czembirek H, Boeck M, Stiskal M. Rheumatoid arthritis: a practical guide to stateof-the-art imaging, image interpretation, and clinical implications. Radiographics 2005;25:381-98.

2. Boutry N, Morel M, Flipo RM, Demondion X, Cotten A. Early rheumatoid arthritis: a review of MRI and sonographic findings. AJR Am J Roentgenol 2007;189:1502-9. 
3. Stewart NR, Crabbe JP, McQueen FM. Magnetic resonance imaging of the wrist in rheumatoid arthritis: demonstration of progression between 1 and 6 years. Skeletal Radiol 2004;33:704-11.

4. Ashikyan $\mathrm{O}$, Tehranzadeh J. The role of magnetic resonance imaging in the early diagnosis of rheumatoid arthritis. Top Magn Reson Imaging 2007;18:169-76.

5. Tehranzadeh J, Ashikyan O, Dascalos J. Advanced imaging of early rheumatoid arthritis. Radiol Clin North Am 2004;42:89-107.

6. Tehranzadeh J, Ashikyan O, Dascalos J. Magnetic resonance imaging in early detection of rheumatoid arthritis. Semin Musculoskelet Radiol 2003;7:79-94.

7. Østergaard M, Ejbjerg B, Szkudlarek M. Imaging in early rheumatoid arthritis: roles of magnetic resonance imaging, ultrasonography, conventional radiography and computed tomography. Best Pract Res Clin Rheumatol 2005;19:91-116.

8. McQueen FM. Magnetic resonance imaging in early inflammatory arthritis: what is its role? Rheumatology (Oxford) 2000;39:700-6.

9. Matsumoto $\mathrm{T}$, Tsurumoto $\mathrm{T}$, Shindo $\mathrm{H}$, Uetani $\mathrm{M}$. Comparative study of fat- suppressed Gd-enhanced MRI of hands in the early stage of rheumatoid arthritis (RA) and non-RA. Mod Rheumatol 2001;11:56-60.

10. Ejbjerg BJ, Vestergaard A, Jacobsen S, Thomsen H, Østergaard $\mathrm{M}$. Conventional radiography requires a MRI-estimated bone volume loss of $20 \%$ to $30 \%$ to allow certain detection of bone erosions in rheumatoid arthritis metacarpophalangeal joints. Arthritis Res Ther 2006;8:R59.

11. Døhn UM, Ejbjerg BJ, Hasselquist M, Narvestad E, Møller J, Thomsen HS, et al. Detection of bone erosions in rheumatoid arthritis wrist joints with magnetic resonance imaging, computed tomography and radiography. Arthritis Res Ther 2008;10:R25.

12. Conaghan PG, Bird P, McQueen F, Peterfy C, Bøyesen P, Gandjbakhch F, et al. The OMERACT MRI inflammatory arthritis group: advances and future research priorities. J Rheumatol 2009;36:1803-5.

13. Gilkeson G, Polisson R, Sinclair H, Vogler J, Rice J, Caldwell D, et al. Early detection of carpal erosions in patients with rheumatoid arthritis: a pilot study of magnetic resonance imaging. J Rheumatol 1988;15:1361-6.

14. Boesen M, Østergaard M, Cimmino MA, Kubassova O, Jensen KE, Bliddal H. MRI quantification of rheumatoid arthritis: current knowledge and future perspectives. Eur J Radiol 2009;71:189-96.

15. Eshed I, Feist E, Althoff CE, Hamm B, Konen E, Burmester GR, et al. Tenosynovitis of the flexor tendons of the hand detected by MRI: an early indicator of rheumatoid arthritis. Rheumatology (Oxford) 2009;48:887-91.
16. Fonseca JE, Canhão H, Tavares NJ, Cruz M, Branco J, Queiroz MV. Persistent low grade synovitis without erosive progression in magnetic resonance imaging of rheumatoid arthritis patients treated with infliximab over 1 year. Clin Rheumatol 2009;28:1213-6.

17. Boers M, Brooks P, Strand CV, Tugwell P. The OMERACT filter for Outcome Measures in Rheumatology. J Rheumatol 1998;25:198-9.

18. Østergaard M, Edmonds J, McQueen F, Peterfy C, Lassere $M$, Ejbjerg $B$, et al. An introduction to the EULAR-OMERACT rheumatoid arthritis MRI reference image atlas. Ann Rheum Dis 2005;64 Suppl 1:i3-7.

19. Ejbjerg B, McQueen F, Lassere M, Haavardsholm E, Conaghan P, O'Connor P, et al. The EULAR-OMERACT rheumatoid arthritis MRI reference image atlas: the wrist joint. Ann Rheum Dis 2005;64 Suppl 1:i23-47.

20. Conaghan PG, O'Connor P, McGonagle D, Astin P, Wakefield RJ, Gibbon WW, et al. Elucidation of the relationship between synovitis and bone damage: a randomized magnetic resonance imaging study of individual joints in patients with early rheumatoid arthritis. Arthritis Rheum 2003;48:64-71.

21. Haavardsholm EA, Bøyesen P, Østergaard M, Schildvold A, Kvien TK. Magnetic resonance imaging findings in 84 patients with early rheumatoid arthritis: bone marrow oedema predicts erosive progression. Ann Rheum Dis 2008;67:794-800.

22. Sugimoto H, Takeda A, Masuyama J, Furuse M. Earlystage rheumatoid arthritis: diagnostic accuracy of MR imaging. Radiology 1996;198:185-92.

23. McQueen FM, Stewart N, Crabbe J, Robinson E, Yeoman S, Tan PL, et al. Magnetic resonance imaging of the wrist in early rheumatoid arthritis reveals progression of erosions despite clinical improvement. Ann Rheum Dis 1999;58:156-63.

24. Yao L, Magalnick M, Wilson M, Lipsky P, GoldbachMansky R. Periarticular bone findings in rheumatoid arthritis: T2-weighted versus contrast-enhanced T1-weighted MRI. AJR Am J Roentgenol 2006;187:358-63.

25. Tanaka N, Sakahashi H, Ishii S, Sato E, Hirose K, Ishima T. Synovial membrane enhancement and bone erosion by magnetic resonance imaging for prediction of radiologic progression in patients with early rheumatoid arthritis. Rheumatol Int 2005;25:103-7.

26. Peterfy CG. MRI of the wrist in early rheumatoid arthritis. Ann Rheum Dis 2004;63:473-7.

27. McQueen FM, Ostendorf B. What is MRI bone oedema in rheumatoid arthritis and why does it matter? Arthritis Res Ther 2006;8:222.

28. Fleming A, Crown JM, Corbett M. Incidence of joint involvement in early rheumatoid arthritis. Rheumatol Rehabil 1976;15:92-6.

29. Arnett FC, Edworthy SM, Bloch DA, McShane DJ, Fries JF, Cooper NS, et al. The American Rheumatism Association 1987 revised criteria for the classification of rheumatoid arthritis. Arthritis Rheum 1988;31:315-24. 
30. Boers M. Rheumatoid arthritis. Treatment of early disease. Rheum Dis Clin North Am 2001;27:405-14.

31. Machold KP, Stamm TA, Eberl GJ, Nell VK, Dunky A, Uffmann $M$, et al. Very recent onset arthritis-clinical, laboratory, and radiological findings during the first year of disease. J Rheumatol 2002;29:2278-87.
32. Backhaus M, Burmester GR, Sandrock D, Loreck D, Hess D, Scholz A, et al. Prospective two year follow up study comparing novel and conventional imaging procedures in patients with arthritic finger joints. Ann Rheum Dis 2002;61:895-904.

33. Kirwan JR. The relationship between synovitis and erosions in rheumatoid arthritis. Br J Rheumatol 1997;36:225-8. 